\title{
The impact of a nutrition education programme on the anthropometric nutritional status of low-income children in South Africa
}

\author{
CM Walsh ${ }^{1, *}$, A Dannhauser ${ }^{2}$ and $G$ Joubert $^{3}$ \\ 'School of Tourism, Hospitality and Sport, Technikon Free State, Private Bag X20539, Bloemfontein 9300, \\ South Africa: ${ }^{2}$ Department of Human Nutrition, University of the Free State, Bloemfontein, South Africa: \\ ${ }^{3}$ Department of Biostatistics, University of the Free State, Bloemfontein, South Africa
}

Submitted 10 December 1998: Accepted 30 May 2001

\begin{abstract}
Objective: The study determined the impact of a community-based nutrition education programme, using trained community nutrition advisors, on the anthropometric nutritional status of mixed-race children aged between 2 and 5 years. Design and setting: The programme was implemented over two years in four study areas in the Free State and Northern Cape Provinces. Two control areas were included to differentiate between the effect of the education programme and a food aid programme that were implemented simultaneously. Weight-for-age, height-forage and weight-for-height were summarised using standard deviations from the NCHS reference median. For each of the indicators, the difference in the percentage of children below minus two standard deviations from the reference NCHS median in the initial and follow-up surveys was determined.

Subjects: Initially 536 children were measured and, after two years of intervention, 815.

Results: Weight-for-age improved in all areas, but only significantly in boys and girls in the urban study area, and in boys in one rural study area. No significant improvement in height-for-age occurred in any area. Weight-for-height improved significantly in the urban study area.

Conclusion: The education programme in combination with food aid succeeded in improving the weight status of children, but was unable to facilitate catch-up growth in stunted children after two years of intervention.
\end{abstract}

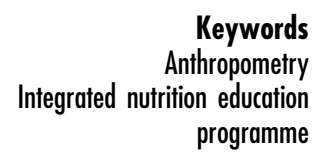

Anthropometry

programme
According to the United Nations (International) Children's (Emergency) Fund (UNICEF) ${ }^{1}$, all people have the right to be free from hunger and malnutrition. Despite this basic human right, about 150 million children under 5 years old are underweight, and another 20 million suffer from severe malnutrition ${ }^{1}$. In South Africa, the previous lack of a national nutrition surveillance programme has made it difficult to determine the prevalence of malnutrition. Single studies seem to indicate, however, that it is as high as 30\% in African and mixed-race children. The extent of nutritionally related diseases in African ${ }^{2-15}$ and mixedrace $^{4,11,16-20}$ communities in South Africa seems to indicate that dietary practices leave much to be desired.

The implications of malnutrition are considerable, not only as a health problem, but also as a developmental and economic problem. While considerable effort has been made to determine the prevalence of malnutrition, much less attention has been given to prevention. Yet, information about prevalence is of little value unless related to action.

The Nutrition Education Intervention Programme (NEIP) has been developed based on the nutrition education programme of the previous Administration: House of Representatives, to address the malnutrition problem of low-income children of mixed race in the Free State and Northern Cape Provinces.

\section{Subjects and methods}

The NEIP consisted of an intensive nutrition education programme implemented with the help of nutrition advisors, appointed as community health workers and remunerated by the government. Advisors are local respected members of communities with nutrition as 
first priority. Advisors were trained and supervised in the community, with each month in the two-year implementation period devoted to a different topic of nutrition (all topics were covered twice). The programme was adapted to local conditions, depending on specific needs. While nutrition advisors were in training they were visited every second week by a supervisor and at least once a month after training was completed.

Nutrition advisors concentrate on improving nutritional knowledge about a variety of relevant topics such as balanced meals, food purchasing and preparation, and nutrition during the different life cycles. Advisors are also involved in nutrition monitoring (growth and breastfeeding) and community development. An objective of the NEIP is to equip communities with knowledge through practical instruction including demonstration, role-play, exhibitions, workshops and home visits. Communities are encouraged to participate by planning actions to generate income and improve household food security. Such plans include women's sewing groups and vegetable gardening projects.

At the time of the study a food aid programme, The National Nutrition and Social Development Programme (NNSDP), was implemented by the government. Needy families were provided with food parcels including staple foods such as corn meal, oil, legumes and milk powder. The food aid programme and the NEIP were implemented in study areas. In the two control areas the food aid programme was implemented, but no nutrition education was given.

The townships that were included are all relatively uniform as regards climate, socio-economic status and health services. No major nutrition interventions had previously been implemented in the sample areas. An urban area (Heidedal), a large rural area (Ritchie) and two small rural areas (Jagersfontein and Fauresmith) comprised the study areas. For practical reasons, two rural control areas (Trompsburg and Bethulie) were included because they are relatively close to the other towns and the NNSDP had not been launched in these areas at that time. An urban control area was not included. This may be considered a limitation of the study, but since nutrition advisors had been appointed in all other urban areas in the two provinces, no urban control area remained. In addition, the results of a representative household survey indicated that the level of nutritional knowledge in the urban area was generally no different from that in the rural areas.

All children aged 2 to 5 years were included (mean age ranged from 3.7 years in Bethulie to 4.2 years in Trompsburg for boys and from 3.8 years in Bethulie to 4.3 years in Fauresmith for girls). Initially 536 children were weighed and measured and, after two years, 815 children were included.

Children were weighed to the nearest $0.2 \mathrm{~kg}$ without shoes and heavy clothing. Scales were calibrated before use, and again after every 20 children were weighed. Height was measured using an accurate, non-stretchable measuring tape that was securely fastened to a wall. Children were measured without shoes, standing against the wall with heels touching the wall. A $90^{\circ}$ triangle was used to read the standing height accurately, to the nearest $0.1 \mathrm{~cm}$.

Indices used for the interpretation of weight and height include weight-for-age, height-for-age and weight-forheight $^{21}$. Results were compared with the National Center for Health Statistics (NCHS) references, which were developed using data from the Fels Research Institute and US Health Examination Surveys ${ }^{22}$. Below minus two standard deviations $(<-2 \mathrm{SD})$ from the NCHS median has been used as cut-off point to identify low weight-for-age (underweight), low height-for-age (stunting) and low weight-for-height (wasting). The differences in the percentage of children with anthropometric indicators below -2SD before and after intervention were determined in accordance with World Health Organization (WHO) recommendations ${ }^{21}$ and the 95\% confidence interval (CI) calculated to indicate significance of differences.

\section{Results}

\section{Weight-for-age}

Initially, the percentage of children in Heidedal with a weight-for-age below -2SD (severely underweight) was $34.8 \%$ for boys and $32.2 \%$ for girls. In the rural areas it ranged from $23.8 \%$ in Jagersfontein to $45.5 \%$ in Ritchie for boys and from $15.0 \%$ in Bethulie to $65.0 \%$ in Trompsburg for girls. Also cause for concern is the large percentage of boys and girls in each area that have a weight-for-age between $-2 \mathrm{SD}$ and $-1 \mathrm{SD}$, and who are thus at risk of becoming more seriously underweight (Table 1).

The percentage of severely underweight children decreased quite dramatically between the two surveys in most sample areas (significantly for boys and girls in Heidedal and for boys in Ritchie) (Table 4). In Heidedal, it had more than halved after two years of nutrition intervention. The same trend was observed in the boys in Ritchie, where severe underweight decreased from $45.5 \%$ to only $23.9 \%$ (Table 1 ). In the remaining two study areas and control areas an improvement was also observed (with the exception of girls in Bethulie). The small sample sizes make it difficult, however, to interpret the data in these areas.

As a result of the decrease in severely underweight children, the percentage of less severely underweight or normal weight children (weight-for-age above -2SD) increased.

\section{Height-for-age}

During the initial survey $27.6 \%$ of boys and $23.8 \%$ of girls in Heidedal were stunted (height-for-age below -2SD). 
Table 1 Weight-for-age

\begin{tabular}{|c|c|c|c|c|c|c|c|c|c|c|c|c|}
\hline & \multicolumn{8}{|c|}{ Study areas } & \multicolumn{4}{|c|}{ Control areas } \\
\hline & \multicolumn{2}{|c|}{ Heidedal } & \multicolumn{2}{|c|}{ Ritchie } & \multicolumn{2}{|c|}{ Jagersfontein } & \multicolumn{2}{|c|}{ Fauresmith } & \multicolumn{2}{|c|}{ Trompsburg } & \multicolumn{2}{|c|}{ Bethulie } \\
\hline & 1 & 2 & 1 & 2 & 1 & 2 & 1 & 2 & 1 & 2 & 1 & 2 \\
\hline $\begin{array}{l}\text { Boys } \\
\text { SD* }^{*}\end{array}$ & $n=141$ & $n=152$ & $n=44$ & $n=138$ & $n=21$ & $\begin{array}{r}n=38 \\
\%\end{array}$ & $n=21$ & $n=20$ & $n=20$ & $n=16$ & $n=23$ & $n=22$ \\
\hline $\begin{array}{l}<-3 \\
-3 \text { to }-2 \\
-2 \text { to }-1 \\
-1 \text { to } 1 \\
\geq 1\end{array}$ & \begin{tabular}{r|}
12.1 \\
22.7 \\
32.6 \\
29.8 \\
2.8
\end{tabular} & $\begin{array}{r}0.7 \\
7.9 \\
27.6 \\
58.6 \\
5.3\end{array}$ & $\begin{array}{r}9.1 \\
36.4 \\
29.6 \\
25.0 \\
0.0\end{array}$ & \begin{tabular}{r|}
3.6 \\
20.3 \\
42.8 \\
32.6 \\
0.7
\end{tabular} & $\begin{array}{r}0.0 \\
23.8 \\
33.3 \\
42.9 \\
0.0\end{array}$ & $\begin{array}{r}2.6 \\
13.2 \\
47.4 \\
36.8 \\
0.0\end{array}$ & $\begin{array}{r}0.0 \\
33.3 \\
42.9 \\
23.8 \\
0.0\end{array}$ & $\begin{array}{r}0.0 \\
20.0 \\
55.0 \\
25.0 \\
0.0\end{array}$ & $\begin{array}{r}10.0 \\
30.0 \\
30.0 \\
30.0 \\
0.0\end{array}$ & \begin{tabular}{r|}
6.3 \\
18.7 \\
43.7 \\
31.3 \\
0.0
\end{tabular} & \begin{tabular}{r|}
8.7 \\
30.4 \\
17.4 \\
43.5 \\
0.0
\end{tabular} & $\begin{array}{r}9.1 \\
4.6 \\
22.7 \\
59.1 \\
4.6\end{array}$ \\
\hline $\begin{array}{l}\text { Girls } \\
\text { SD*}^{*}\end{array}$ & $n=143$ & $n=186$ & $n=50$ & $n=147$ & $n=17$ & $\begin{array}{r}n=36 \\
\%\end{array}$ & $n=16$ & $n=21$ & $n=20$ & $n=19$ & $n=20$ & $n=21$ \\
\hline $\begin{array}{l}<-3 \\
-3 \text { to }-2 \\
-2 \text { to }-1 \\
-1 \text { to } 1 \\
\geq 1\end{array}$ & $\begin{array}{r}13.3 \\
18.9 \\
27.3 \\
37.8 \\
2.8\end{array}$ & $\begin{array}{r}1.6 \\
10.8 \\
27.4 \\
52.2 \\
8.1\end{array}$ & $\begin{array}{r}12.0 \\
22.0 \\
40.0 \\
22.0 \\
4.0\end{array}$ & $\begin{array}{r}6.1 \\
15.7 \\
41.4 \\
36.1 \\
0.7\end{array}$ & $\begin{array}{r}0.0 \\
29.4 \\
23.5 \\
41.2 \\
5.9\end{array}$ & $\begin{array}{r}0.0 \\
19.4 \\
41.7 \\
36.1 \\
2.8\end{array}$ & $\begin{array}{r}0.0 \\
43.8 \\
43.8 \\
12.5 \\
0.0\end{array}$ & $\begin{array}{r}14.3 \\
28.5 \\
38.1 \\
19.1 \\
0.0\end{array}$ & $\begin{array}{r}20.0 \\
45.0 \\
30.0 \\
5.0 \\
0.0\end{array}$ & $\begin{array}{r}15.8 \\
21.1 \\
26.3 \\
36.8 \\
0.0\end{array}$ & $\begin{array}{r}5.0 \\
10.0 \\
45.0 \\
35.0 \\
5.0\end{array}$ & $\begin{array}{r}0.0 \\
20.0 \\
25.0 \\
50.0 \\
5.0\end{array}$ \\
\hline
\end{tabular}

* Standard deviation (SD) from the reference NCHS median.

1 = Before intervention; 2 = after intervention.

In rural areas stunting ranged from $20.0 \%$ in Bethulie to 81.3\% in Fauresmith. As with weight-for-age, a large percentage of children had a height-for-age between $-2 \mathrm{SD}$ and $-1 \mathrm{SD}$.

In contrast to the weight-for-age findings, the percentage of stunted children actually increased after intervention (by as much as $8.6 \%$ for boys and $11.1 \%$ for girls in Heidedal). The prevalence of stunting decreased by $13.6 \%$ for boys in Ritchie and by $23.6 \%$ for girls in Trompsburg, but in other study and control areas the percentage of children with a height-for-age below -2SD either increased (significantly in Jagersfontein) or remained essentially the same (Table 2). Again it must be emphasised that the data of small rural sample sizes must be interpreted cautiously, since the data of one child can affect the results significantly.

\section{Weight-for-beight}

The prevalence of wasting (weight-for-height below -2SD) was relatively low in all rural areas (ranging from $0 \%$ in Jagersfontein and Fauresmith to $13.7 \%$ in Ritchie), but higher in urban Heidedal (21.3\% for boys and $21.7 \%$ for girls). This difference is probably due to a more acute food shortage in Heidedal than in the rural areas, where stunting due to chronic malnutrition often results in a 'normal' weight-for-height, despite the low weight-for-age.

A decrease in the percentage of wasted children was observed after intervention in most sample areas (Table 3). The difference was significant in Heidedal where it decreased to $0.7 \%$ in boys and $2.7 \%$ in girls (Table 4), the reason being that a larger proportion of urban children were wasted during the initial survey, leaving room for

Table 2 Height-for-age

\begin{tabular}{|c|c|c|c|c|c|c|c|c|c|c|c|c|}
\hline & \multicolumn{8}{|c|}{ Study areas } & \multicolumn{4}{|c|}{ Control areas } \\
\hline & \multicolumn{2}{|c|}{ Heidedal } & \multicolumn{2}{|c|}{ Ritchie } & \multicolumn{2}{|c|}{ Jagersfontein } & \multicolumn{2}{|c|}{ Fauresmith } & \multicolumn{2}{|c|}{ Trompsburg } & \multicolumn{2}{|c|}{ Bethulie } \\
\hline & 1 & 2 & 1 & 2 & 1 & 2 & 1 & 2 & 1 & 2 & 1 & 2 \\
\hline $\begin{array}{l}\text { Boys } \\
\text { SD* }^{*}\end{array}$ & $n=141$ & $n=152$ & $n=44$ & $n=138$ & $n=21$ & $\begin{array}{r}n=38 \\
\%\end{array}$ & $n=21$ & $n=20$ & $n=20$ & $n=16$ & $n=23$ & $n=22$ \\
\hline $\begin{array}{l}<-3 \\
-3 \text { to }-2 \\
-2 \text { to }-1 \\
-1 \text { to } 1 \\
\geq 1\end{array}$ & $\begin{array}{r}9.9 \\
17.7 \\
22.7 \\
42.6 \\
7.1\end{array}$ & $\begin{array}{r}12.5 \\
23.7 \\
36.2 \\
22.4 \\
5.3\end{array}$ & \begin{tabular}{r|}
13.6 \\
31.8 \\
36.4 \\
18.2 \\
0.0
\end{tabular} & $\begin{array}{r}10.1 \\
21.7 \\
31.9 \\
33.3 \\
2.9\end{array}$ & $\begin{array}{r}33.3 \\
19.1 \\
23.8 \\
23.8 \\
0.0\end{array}$ & $\begin{array}{r}52.6 \\
31.6 \\
10.5 \\
5.3 \\
0.0\end{array}$ & \begin{tabular}{r|}
33.3 \\
19.1 \\
33.3 \\
14.3 \\
0.0
\end{tabular} & $\begin{array}{r}50.0 \\
30.0 \\
15.0 \\
5.0 \\
0.0\end{array}$ & $\begin{array}{r}15.0 \\
20.0 \\
40.0 \\
20.0 \\
5.0\end{array}$ & $\begin{array}{r}18.8 \\
18.8 \\
37.5 \\
25.0 \\
0.0\end{array}$ & $\begin{array}{r}13.0 \\
34.8 \\
13.1 \\
39.1 \\
0.0\end{array}$ & $\begin{array}{r}18.2 \\
27.3 \\
31.8 \\
22.7 \\
0.0\end{array}$ \\
\hline $\begin{array}{l}\text { Girls } \\
\text { SD*}^{*}\end{array}$ & $n=143$ & $n=186$ & $n=50$ & $n=147$ & $n=17$ & $\begin{array}{r}n=36 \\
\%\end{array}$ & $n=16$ & $n=21$ & $n=20$ & $n=19$ & $n=20$ & $n=21$ \\
\hline $\begin{array}{l}<-3 \\
-3 \text { to }-2 \\
-2 \text { to }-1 \\
-1 \text { to } 1 \\
\geq 1\end{array}$ & $\begin{array}{r}9.8 \\
14.0 \\
25.9 \\
41.3 \\
9.1\end{array}$ & $\begin{array}{r}9.1 \\
25.8 \\
29.6 \\
33.3 \\
2.2\end{array}$ & $\begin{array}{r}10.0 \\
20.0 \\
40.0 \\
26.0 \\
4.0\end{array}$ & $\begin{array}{r}10.9 \\
24.5 \\
27.9 \\
33.3 \\
3.4\end{array}$ & $\begin{array}{r}29.4 \\
17.7 \\
17.7 \\
29.4 \\
5.9\end{array}$ & $\begin{array}{r}50.0 \\
38.9 \\
8.3 \\
0.0 \\
2.8\end{array}$ & \begin{tabular}{r|}
31.3 \\
50.0 \\
12.5 \\
6.2 \\
0.0
\end{tabular} & $\begin{array}{r}61.9 \\
23.8 \\
9.5 \\
0.0 \\
4.8\end{array}$ & $\begin{array}{r}20.0 \\
30.0 \\
40.0 \\
10.0 \\
0.0\end{array}$ & $\begin{array}{r}21.1 \\
5.3 \\
42.1 \\
31.6 \\
0.0\end{array}$ & $\begin{array}{r}5.0 \\
15.0 \\
35.0 \\
35.0 \\
10.0\end{array}$ & $\begin{array}{r}10.0 \\
15.0 \\
40.0 \\
30.0 \\
5.0\end{array}$ \\
\hline
\end{tabular}

* Standard deviation (SD) from the reference NCHS median.

1 = Before intervention; 2 = after intervention. 
Table 3 Weight-for-height

\begin{tabular}{|c|c|c|c|c|c|c|c|c|c|c|c|c|}
\hline & \multicolumn{8}{|c|}{ Study areas } & \multicolumn{4}{|c|}{ Control areas } \\
\hline & \multicolumn{2}{|c|}{ Heidedal } & \multicolumn{2}{|c|}{ Ritchie } & \multicolumn{2}{|c|}{ Jagersfontein } & \multicolumn{2}{|c|}{ Fauresmith } & \multicolumn{2}{|c|}{ Trompsburg } & \multicolumn{2}{|c|}{ Bethulie } \\
\hline & 1 & 2 & 1 & 2 & 1 & 2 & 1 & 2 & 1 & 2 & 1 & 2 \\
\hline $\begin{array}{l}\text { Boys } \\
\text { SD** }\end{array}$ & $n=141$ & $n=152$ & $n=44$ & $n=138$ & $n=21$ & $\begin{array}{r}n=38 \\
\%\end{array}$ & $n=21$ & $n=20$ & $n=20$ & $n=16$ & $n=23$ & $n=22$ \\
\hline$<-3$ & 5.0 & 0.0 & 2.3 & 0.0 & 0.0 & 0.0 & 0.0 & 0.0 & 0.0 & 6.3 & 0.0 & 0.0 \\
\hline-3 to -2 & 16.3 & 0.7 & 11.4 & 5.8 & 0.0 & 0.0 & 0.0 & 0.0 & 5.0 & 0.0 & 8.7 & 0.0 \\
\hline-2 to -1 & 31.9 & 7.2 & 27.3 & 25.4 & 9.5 & 0.0 & 19.1 & 5.0 & 35.0 & 25.0 & 21.7 & 13.6 \\
\hline-1 to 1 & 43.3 & 67.1 & 56.8 & 67.4 & 71.4 & 63.2 & 71.4 & 70.0 & 60.0 & 68.8 & 65.2 & 72.7 \\
\hline$\geq 1$ & 3.5 & 25.0 & 2.3 & 1.5 & 19.1 & 36.9 & 9.5 & 25.0 & 0.0 & 0.0 & 4.4 & 13.7 \\
\hline $\begin{array}{l}\text { Girls } \\
\text { SD** }^{*}\end{array}$ & $n=143$ & $n=186$ & $n=50$ & $n=147$ & $n=17$ & $\begin{array}{r}n=36 \\
\%\end{array}$ & $n=16$ & $n=21$ & $n=20$ & $n=19$ & $n=20$ & $n=21$ \\
\hline$<-3$ & 7.0 & 0.0 & 8.0 & 0.7 & 0.0 & 0.0 & 0.0 & 0.0 & 5.0 & 0.0 & 0.0 & 0.0 \\
\hline-3 to -2 & 14.7 & 2.7 & 2.0 & 2.7 & 0.0 & 0.0 & 0.0 & 0.0 & 10.0 & 5.3 & 10.0 & 0.0 \\
\hline-2 to -1 & 31.5 & 6.5 & 32.0 & 21.8 & 17.7 & 2.8 & 31.3 & 9.5 & 40.0 & 10.5 & 20.0 & 20.0 \\
\hline-1 to 1 & 43.4 & 61.3 & 58.0 & 70.1 & 52.9 & 47.2 & 56.3 & 57.1 & 45.0 & 84.2 & 60.0 & 65.0 \\
\hline$\geq 1$ & 3.5 & 29.6 & 0.0 & 4.8 & 29.5 & 50.0 & 12.5 & 33.3 & 0.0 & 0.0 & 10.0 & 15.0 \\
\hline
\end{tabular}

* Standard deviation (SD) from the reference NCHS median.

1 = Before intervention; 2 = after intervention.

improvement. In rural areas the prevalence of stunting decreased further, or remained as low as in the initial survey. Either no change or a decrease in the percentage of children with a weight-for-height between -2SD and $-1 \mathrm{SD}$ was also noted.

\section{Discussion}

Anthropometric data serve as indicators of various factors, including dietary practices. Advantages of anthropometry above other methods of determining nutritional status in communities have been established ${ }^{21}$. Although there is controversy regarding the use of growth standards for all ethnic groups ${ }^{23,24}$, the use of the NCHS data as references in all communities is indicated ${ }^{1,25}$. Nevertheless, it is important to note that improved anthropometry is not necessarily the most important objective of intervention, nor is it always the best measure of its success ${ }^{26}$.

The nutritional status of mixed-origin children has been reported to be less than satisfactory in other relevant studies $^{19}$. According to Steyn et al. ${ }^{19}$, the largest percentage of children with reduced height and weight in South Africa are rural children of mixed origin. In the light of such findings, the importance of implementing programmes such as the NEIP in needy communities is warranted.

\section{Weight-for-age}

A weight-for-age below $-2 \mathrm{SD}$ is indicative of underweight, which usually occurs after a period of recent food shortage $^{27}$. This index, however, fails to differentiate between children who are tall and thin and children who are short with an adequate weight ${ }^{28}$. The prevalence of underweight in our study was similar to that found by other researchers using the third percentile (which corresponds to $-2 \mathrm{SD}$ ) as cut-off point ${ }^{17,29}$. In a study undertaken amongst 11-year-old children by Steyn et al. ${ }^{19}$, the prevalence of underweight was lower than that found in our study (28\% using the fifth percentile as cut-off point).

After two years of nutrition intervention, the prevalence of underweight had decreased in both the study and control areas, but only significantly in two study areas. A combination of nutrition instruction and food aid is, apparently, more beneficial in improving weight-for-age than food aid in isolation. These results are similar to those found at Pholela Health Centre in rural Natal, South Africa, where a significant improvement in weight-for-age was found after community-based nutrition education focusing on mothers and infants ${ }^{30}$.

\section{Height-for-age}

A height-for-age below $-2 \mathrm{SD}$ is indicative of stunting, which usually occurs after a period of chronic malnutri$\operatorname{tion}^{27}$. Waterlow et al. ${ }^{24}$ reported that height-for-age is the most suitable indicator of past nutrition and, according to Gorstein et $\mathrm{al}^{28}$, stunting is also commonly associated with poor socio-economic conditions. The prevalence of stunting was high before intervention (approximately one-quarter of urban and almost half of rural children), with no marked differences between boys and girls. The fact that socio-economic conditions are generally better in urban areas could possibly explain the lower prevalence of stunting in Heidedal. The prevalence of stunting in our study is, however, higher than that found in mixed-origin children by other researchers. Such studies include that of Margo et al. ${ }^{17}$, who reported stunting figures of $16.1 \%$ among urban children between 1 and 16 years old. Similarly, Steyn et al. ${ }^{19}$ reported that $32 \%$ of 11 -year-old children were stunted, using the fifth percentile as cut-off point.

In contrast to weight-for-age, no significant improve- 


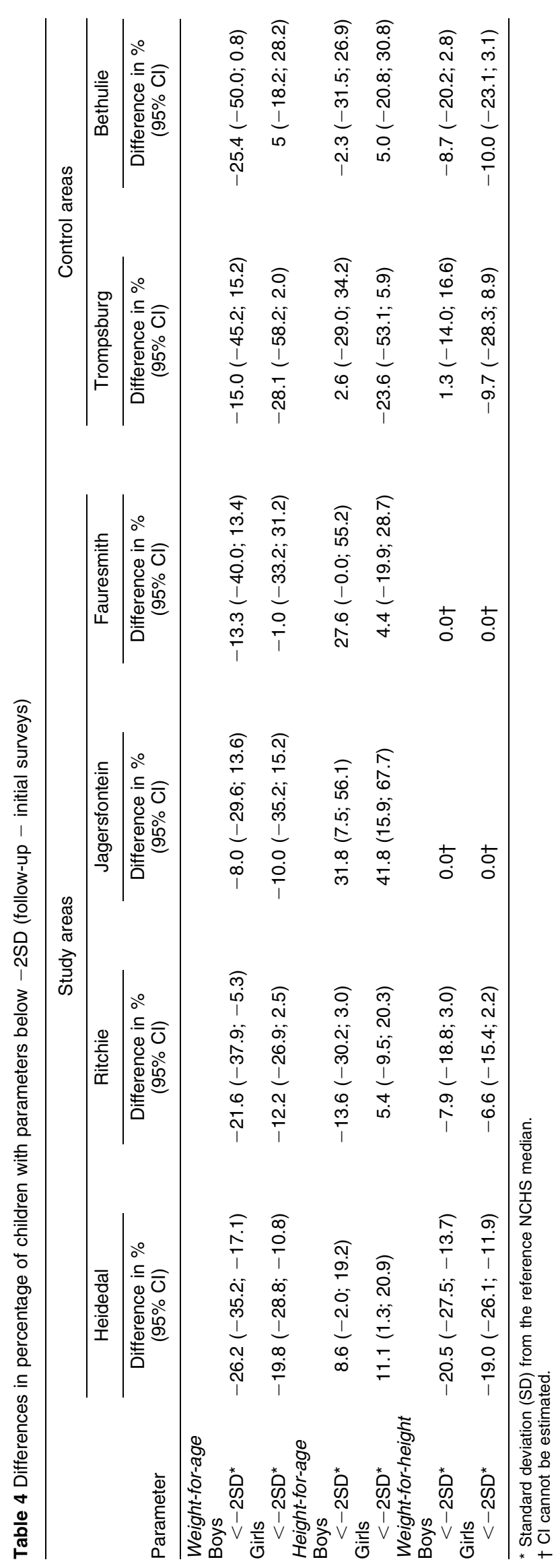

ment in height-for-age was observed after intervention. Weight is the first indicator to respond to nutrition intervention, with linear growth retardation taking much longer to be remedied. Stunting is a condition that occurs as a result of prolonged malnutrition. Just as it takes longer to develop stunting than underweight, so it possibly also takes longer for catch-up growth to occur in stunted children. It is also unlikely that stunted children will ever reach their full growth potential ${ }^{25,28,31}$. Controversy exists regarding the benefits of food aid for stunted children ${ }^{32}$. Despite supplementation, studies have reported that significant catch-up growth does not necessarily occur in stunted children living in low socioeconomic conditions who receive food aid after the age of 1 year $^{32}$ or 3 years ${ }^{33}$. In the light of these findings, it is recommended that stunting be prevented by ensuring optimal nutrition for infants. The benefits of good breastfeeding and weaning practices in this regard are obvious. In addition to food aid, it seems reasonable to suggest that poor environmental conditions, such as household food insecurity, ineffective health care, poor housing and unemployment, need to be addressed in intervention programmes aimed at reducing the prevalence of stunting $^{25}$. Although the NEIP was concerned with increasing household food security by improving knowledge of nutrition, promoting breast-feeding and encouraging income generation, problems such as inadequate housing and health services were beyond the scope of the programme.

\section{Weight-for-beight}

A weight-for-height below $-2 \mathrm{SD}$ is an indication of wasting that usually occurs after a period of recent and severe malnutrition ${ }^{27}$. According to Waterlow et al. $^{24}$, weight-for-height is the most suitable indicator of the present state of nutrition. In contrast to the high prevalence of wasting reported in other studies ${ }^{34}$, fewer urban and rural children in our study were wasted. As found in other studies ${ }^{19}$, the prevalence of wasting in our study was lower than that of underweight and stunting. In the urban area of Heidedal, however, the percentage of wasted children in the initial survey was higher than in rural areas. It is possible that these children had failed to gain weight or had lost weight shortly before the initial survey for some reason. The significant improvement in Heidedal probably points to specific differences in the type of malnutrition that occurs commonly in urban and rural areas (as indicated in the initial survey).

\section{Conclusion}

In interpreting the results obtained by the three chosen indicators, it is important to note that an acute food shortage will undoubtedly produce thin children, irrespective of their height or age ${ }^{27}$. An increase in food intake will improve the weight-for-height and weight-for- 
age of malnourished children, but it may not necessarily affect the height-for-age.

In this study the prevalence of stunting was generally found to be high, with low wasting. Rural areas were more seriously affected than the urban area. According to Gorstein et $a l^{28}$, this situation is common in communities where socio-economic conditions are poor. The NEIP in combination with food aid succeeded in improving the weight status of children, but was unable to facilitate catch-up growth in stunted children after two years of intervention.

It is recommended that socio-economic variables, such as sanitation, housing, literacy and employment, be included in integrated interventions if the overall prevalence of stunting is to be decreased.

\section{Acknowledgements}

The financial assistance of the Centre for Science Development towards this research is hereby acknowledged. The authors would like to thank the nutrition advisors, namely Mrs I Taylor, Mrs C Rynford and Mrs M Fredericks, as well as the nutritionists who helped with the surveys, Mrs R Erasmus, Mrs D Henegan, Mrs A van der Walt and Mrs M le Roux.

\section{References}

1 United Nations (International) Children's (Emergency) Fund (UNICEF). Strategy for Improved Nutrition of Children and Women in Developing Countries. A UNICEF Policy Review. New York: UNICEF, 1992.

2 Westcott GM, Stott RAP. The extent and causes of malnutrition in children in the Tsolo district of Transkei. $S$. Afr. Med. J. 1977; 52(December): 963-8.

3 Richardson BD. Growth patterns of South African children: an overview. S. Afr. J. Sci. 1978; 74: 246-9.

4 Kotzè JP, Van der Merwe GJ, Mostert WP, Reynders JJ, Barnard SO, Snyman N. Anthropometric survey of different cultural groups in South Africa. J. Diet Home Econ. 1980; 10: $77-81$.

5 Cleaton-Jones P, Granath L, Richardson B. Dental Caries, Nutrient Intake, Dietary Habits, Anthropometric Status, Oral Hygiene, and Salivary Factors and Microbiota in South African Black, Indian and White 4-5 year-old children. Report of the Medical Research Council. Parow: Medical Research Council, 1991.

6 Albertyn EW, van der Walt E. 'n Antropometriese voedingstatusopname onder jong kinders in Botshabelo. Geneeskunde 1986; 28: 146-8.

7 Albertyn EW, van der Walt E, Meintjies W, Chaka P, Spoelstra SI. ' $n$ Antropometriese voedingstatusopname onder jong kinders in Botshabelo (OVS). Geneeskunde 1986; 28: 99-106.

8 Hugo-Hamman C, Kibel MA, Michie CA, Yach D. Nutrition status of preschool children in a Cape Town township. $S$. Afr. Med.J. 1987; 72: 353-5.

9 Househam KC, Elliott E. Nutritional status of black children under 5 years old attending a municipal clinic in Bloemfontein. S. Afr. Med. J. 1987; 71: 494.

10 Badenhorst CJ, Steyn NP, Jooste PL, Nel JH, Kruger M,
Oelofse A, Barnard C. Nutritional status of Pedi schoolchildren aged 6-14 years in two rural areas of Lebowa: a comprehensive nutritional survey of dietary intake, anthropometric, biochemical, haematological and clinical measurements. S. Afr J. Food Sci. Nutr. 1993; 5: 112-9.

11 Nutrition Committee. Integrated Nutrition Strategy for South Africa. Unpublished Report, Pretoria, 1994; 11-108.

12 Steyn NP, Nel JH, Tichelaar HY, Prinsloo JF, Dhansay MA, Oelofse A, Benade AJS. Malnutrition in Pedi preschool children, their siblings and caretakers. S. Afr. J. Clin. Nutr. 1994; 7: 12-8

13 Coutsoudis A, Jinabhai CC, Coovadia HM, Mametja LD. Determining appropriate nutritional interventions for South African children living in informal urban settlements. S. Afr. Med.J. 1994; 84: 597-600.

14 Labadarios D, Van Middelkoop A, eds. Children aged 6 to 71 months in South Africa, 1994: Their Anthropometric, Vitamin A, Iron and Immunisation Coverage Status. Johannesburg: The South African Vitamin A Consultative Group (SAVACG), 1995.

15 Dannhauser A, Joubert G, Nel M. Nutritional status of preschool children in the Bloemfontein district. S. Afr. J. Food Sci. Nutr. 1996; 8: 14-22.

16 Lurie GM, Ford FJ. Heights and weights of European and coloured school children in Cape Town. S. Afr. Med.J. 1958; 14(October): 1017-25.

17 Margo G, Baroni Y, Brindley M, Green R, Metz J. Protein energy malnutrition in coloured children in Western Township, Johannesburg. S. Afr. Med. J. 1976; 50(July): 1241-5.

18 Power DJ. An anthropometric study of young schoolchildren in an area of Cape Town. S. Afr. Med. J. 1982; 61(February): 303-5.

19 Steyn NP, Wicht CL, Rossouw JE, Kotze TJVW, van Eck M. Nutritional status of 11-year-old children in the Western Cape. II. Anthropometry. S. Afr. J. Food Sci. Nutr. 1989; 1: $21-7$.

20 Steyn NP, Pettifor JM, van der Westhuyzen J, van Niekerk L. Nutritional status of schoolchildren in the Richtersveld. $S$. Afr. J. Food Sci. Nutr. 1990; 2: 52-6.

21 World Health Organization (WHO). Measuring Change in Nutritional Status: Guidelines for Assessing the Nutritional Impact of Supplementary Feeding Programmes for Vulnerable Groups. Geneva: WHO, 1983.

22 Dibley MJ, Goldsby JB, Staehling NW, Towbridge FL. Development of normalized curves for the international growth reference: historical and technical considerations. Am. J. Clin. Nutr. 1987; 46: 736-48.

23 Durnin JVGA. Aspects of anthropometric evaluation of malnutrition in childhood. Acta Paediatr. Scand. Suppl. 1991; 374: 89-94.

24 Waterlow JC, Buzina R, Keller W, Lane JM, Nichaman MZ, Tanner JM. The presentation and use of height and weight data for comparing the nutritional status of groups of children under the age of 10 years. Bull. World Health Org. 1977; 55: 489-98.

25 Gross R, Schultink W, Sastroamidjojo S. Stunting as an indicator for health and wealth: an Indonesian application. Nutr. Res. 1996; 16: 1829-37.

26 ACC/SCN. Second Report on the World Nutrition Situation. Geneva: ACC/SCN, United Nations, 1992.

27 de Onis M, Mmonteiro C, Akrè J, Clugston G. The worldwide magnitude of protein-energy malnutrition: an overview from the WHO Global Database on Child Growth. Bull. World Health Org. 1993; 71: 703-12.

28 Gorstein J, Sullivan K, Yip R, de Onis M, Trowbridge F, Fajans P, Clugston G. Issues in the assessment of nutritional status using anthropometry. Bull. World Health Org. 1994; 72: $273-83$

29 Hansen JDL. Protein-energy malnutrition in South Africa. 
Report on Nutrition Disorders in South Africa: Recommendations for a National Food and Nutrition Policy. Medunsa: The Nutrition Society of Southern Africa, 1989.

30 Tollman SM. The Pholela Health Centre - the origins of community-oriented primary health care (COPC). S. Afr. Med.J. 1994; 84: 653-8.

31 Ashworth A, Millward DJ. Catch-up growth in children. Nutr. Rev. 1986; 44: 157-63.

32 Walker SP, Grantham-McGregor SM, Himes JH, Powell CA,
Chang SM. Early childhood supplementation does not benefit the long-term growth of stunted children in Jamaica. I. Nutr. 1996; 126: 3017-24.

33 Perez-Escamilla R, Pollitt E. Growth improvements in children above 3 years of age: the Cali study. J. Nutr 1995; 125: 885-93.

34 Harrison D. Nutrition Policy in South Africa 1928-1993. Durban: Trust for Health Systems Planning and Development, 1993. 